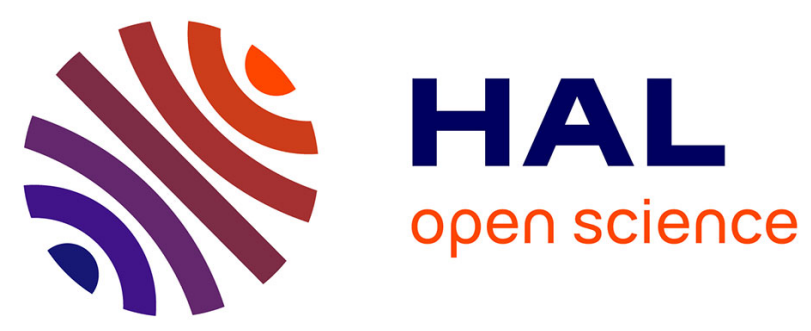

\title{
Impact of a population-based asthma management program in France (Sophia Asthme): A matched controlled before-and-after quasi-experimental study using the French health insurance database (SNDS)
}

Fadia Dib, Yann de Rycke, Sylvie Guillo, Alexandre Lafourcade, Chantal Raherison, Camille Taillé, Florence Tubach

\section{To cite this version:}

Fadia Dib, Yann de Rycke, Sylvie Guillo, Alexandre Lafourcade, Chantal Raherison, et al.. Impact of a population-based asthma management program in France (Sophia Asthme): A matched controlled before-and-after quasi-experimental study using the French health insurance database (SNDS). Pharmacoepidemiology and Drug Safety, 2019, 28 (8), pp.1097-1108. 10.1002/pds.4842 . hal-02289350

\section{HAL Id: hal-02289350 \\ https://hal.sorbonne-universite.fr/hal-02289350}

Submitted on 16 Sep 2019

HAL is a multi-disciplinary open access archive for the deposit and dissemination of scientific research documents, whether they are published or not. The documents may come from teaching and research institutions in France or abroad, or from public or private research centers.
L'archive ouverte pluridisciplinaire HAL, est destinée au dépôt et à la diffusion de documents scientifiques de niveau recherche, publiés ou non, émanant des établissements d'enseignement et de recherche français ou étrangers, des laboratoires publics ou privés. 


\section{Impact of a population-based asthma management program in France} (Sophia Asthme): a matched controlled before-and-after quasi experimental study using the French health insurance database (SNDS)

Fadia Dib *1,2,3 MD, Yann de Rycke Y*4 MSc, Sylvie Guillo ${ }^{4}$ MSc, Alexandre Lafourcade ${ }^{4} \mathrm{MSc}$, Chantal Raherison ${ }^{5,6} \mathrm{MD}-\mathrm{PhD}$, Camille Taillé $\mathrm{C}^{7} \mathrm{MD}-\mathrm{PhD}$, Florence Tubach ${ }^{4} \mathrm{MD}-\mathrm{PhD}$.

*contributed equally

${ }^{1}$ AP-HP, Hôpital Bichat-Claude-Bernard, Département d'Epidémiologie, Biostatistiques et Recherche Clinique, F- 75018 Paris, France

2 INSERM, CIC-EC 1425, 75018, Paris, France

${ }^{3}$ Université Paris Diderot, Sorbonne Paris Cité, ECEVE, UMRS 1123, F-75010 Paris, France ${ }^{4}$ Sorbonne Université, INSERM, Institut Pierre Louis d'épidémiologie et de Santé Publique, IPLESP UMR-S1136, CIC 1421, AP-HP, Hôpital Pitié-Salpêtrière, Département Biostatistique Santé Publique et Information Médicale, Centre de Pharmacoépidémiologie, Céphépi, F75013 Paris, France

${ }^{5}$ INSERM U1219 team EPICENE, Bordeaux University 146 rue Leo Saignat 33076 Bordeaux France

${ }^{6}$ Service des Maladies Respiratoires, CHU Bordeaux, Place Amélie Raba Léon, 33000 Bordeaux

${ }^{7}$ Service de Pneumologie et Centre de Compétence des Maladies Pulmonaires Rares, Hôpital Bichat, AP-HP, Paris et Département Hospitalo-Universitaire FIRE, Université Paris Diderot, INSERM UMR 1152, LabEx Inflamex, Paris, France

Corresponding author: Pr Florence Tubach, AP-HP, Hôpital Pitié-Salpêtrière, Département Biostatistique Santé Publique et Information Médicale, Centre de Pharmacoépidémiologie, Céphépi, Unité de recherche clinique, INSERM, UMR 1123, CIC-P 1421, F-75013 Paris, France. E-mail: florence.tubach@aphp.fr. Tel: 01.42.16.05.88

Key words: Asthma control, Asthma exacerbation, Asthma outcomes, Disease management program 


\section{ABSTRACT}

Background: Sophia Asthme (SA) is a chronic disease management program of the French national health insurance for adult patients with asthma. We evaluated the early impact of this intervention.

Methods: We conducted a matched controlled, before-and-after quasi-experimental study within the French Health Insurance Database (SNDS). The SA program was implemented in a set of 18 Départements in France and targeted 18-to 44-year-old subjects, with at least two reimbursement dates for asthma drug therapy during the 12-month period prior to program targeting. Change in outcomes was assessed from the "before program" period (JanuaryDecember 2014) to the "after program implementation" period (Mars 2015-February 2016) in the program group (eligible to SA program in the 18 Départements) and in the matched controlled group. The main outcome measure was the before-after change in proportion of subjects with a controllers/(controllers+relievers) ratio $>50 \%$.

Findings: Of the 99,578 subjects of the program group, 9,225 (9.3\%) actually participated in SA program. The program had no significant impact on the proportion of subjects with a ratio $>50 \%$. However, subjects exposed to SA program were significantly more likely to be dispensed controller medications (OR=1.04; $95 \% \mathrm{Cl}, 1.01$ to 1.07$)$, and to sustain their use of these medications $(\mathrm{OR}=1 \cdot 08 ; 95 \% \mathrm{Cl}, 1.05$ to $1 \cdot 12)$.

Interpretation: We did not demonstrate any significant impact of the program on the primary outcome. The modest yet encouraging findings of this early evaluation suggest the need for reformulation of the program and its evaluation.

Funding: Caisse Nationale d'Assurance Maladie, Paris, France. 


\section{INTRODUCTION}

62

63

Despite the availability of highly effective therapies, achieving asthma control remains tremendously challenging, mostly because of inappropriate use of asthma controller medications. ${ }^{1}$ Poor asthma control is responsible for acute exacerbations, which can lead to emergency visits, hospitalizations, and even premature deaths. With an estimated global asthma prevalence among adults ranging from $1 \%$ to $21 \%{ }^{2}$ and 383,000 related deaths in $2015,{ }^{3}$ asthma places substantial burdens on the patients, healthcare system and society; ${ }^{4,5}$ it is a major public health problem recognized by the World Health Organization (WHO). ${ }^{3}$

Various programs have been implemented worldwide to improve asthma control. ${ }^{6}$ Sophia Asthme (SA) program is a chronic disease management program developed by the National French Insurance Service (Caisse Nationale de l'Assurance Maladie (CNAM)). It aims to enhance self-management and induce behavior changes, at a sustainable cost to the CNAM budget.

Sophia program was first developed for diabetic patients in 2008 , and included a free web site, written information and telephonic nurse intervention. Recently, a pilot program was developed for asthma patients, aiming at improving asthma control. The objective of this study commissioned by the CNAM was to assess the early effect of the pilot phase of the SA program on asthma outcomes in adult asthma patients. 


\section{METHODS}

\section{Description of the intervention}

As a health insurer, the CNAM defines and implements risk-management actions. In this framework, the CNAM launched the pilot experiment of SA program ${ }^{7}$ in January 2015, in 18 among 96 Départements of mainland France (Alpes-Maritimes, Ariège, Côte-d'Or, HauteGaronne, Gers, Gironde, Hérault, Loire, Loiret, Marne, Meurthe-et-Moselle, Nord, Puy-deDôme, Hautes-Pyrénées, Sarthe, Somme, Tarn, and Seine-Saint-Denis). Targeting the 18- to 44-year-old asthmatic patients, SA program consists primarily of a nurse-delivered, phonebased intervention. Every individual identified in the CNAM claims databases and meeting the selection criteria was invited to take part in the program. The program participants (as opposed to "program non-participants") started receiving phone calls after mail or online registration made by the patient or their general practitioner (GP).

During the first phone call, medical data (asthma control during the last 4 weeks according to Global Initiative for Asthma (GINA) criteria $^{8}$, smoking status and physical exercise practice) were collected. During the following calls, specialized nurses trained in behavioral counseling conducted motivational interviews to promote positive attitudes towards asthma, using a computer-assisted telephone system. Telephone calling periodicity was determined initially and updated afterwards according to a set of criteria reflecting asthma control. After the first phone call, a bimonthly call was planned for patients who had had a hospitalization or ER visit for asthma and for those who had poor symptom control according to GINA criteria. An annual call was planned otherwise. Hospitalization and ER visits for asthma were monitored in real-time (from claims/hospital discharge data) for all program participants, so that patients could benefit from additional calls in the event where asthma hospitalization or 
ER visit occurred since the last phone call. The same criteria were applied after the second

105

call to determine the periodicity of the subsequent calls. These criteria encompassed both asthma control and medical use from the SNDS database. The content of counseling was recorded in a dedicated software, and tailored for each program participant based on its personal situation (lifestyle, state of health and medical care, social and family environment). Nurses offered appropriate advice and information, in order to promote a greater understanding of the relation between medication adherence and asthma control. They urged patients to seek medical aid and drug treatment, when appropriate.

Participants without any telephone call during the intervention period were classified as participants with "low-intensity intervention", those who had one to three and more than three calls as participants with "moderate-intensity and "high-intensity intervention", respectively.

Besides telephone calls, all program participants received printed material developed by health care professionals and validated by a scientific committee. The material included three leaflets and bi-monthly e-newsletters on asthma. The CNAM also provided unrestricted access to a dedicated website. The written material and the website included information on prevention of exacerbations, smoking cessation, physical activity and management of the disease.

\section{Population}

Subjects for the pilot experiment were identified and followed-up within the French Health Insurance database (Système National Des Données de Santé- SNDS). Eligibility criteria for the SA program were the following: 1 ) being aged 18 to 44 years; 2 ) having at least two different reimbursement dates for asthma medications (R03 codes according to the 
Anatomical Therapeutic and Chemical (ATC) classification system) in the last 12 months; 3)

being covered by the general health insurance scheme; 4) being affiliated with a local healthcare insurance office (Caisse Primaire d'Assurance Maladie - CPAM) attached to any of the 18 aforementioned Départements for at least 12 months before program deployment; and 5) having a GP also affiliated with a CPAM attached to any of the 18 aforementioned Départements for at least 12 months before program deployment.

The study population involved all subjects eligible to SA program from Départements with the program (i.e., the exposed) matched on a propensity score and stratification variables, with subjects eligible to SA program except they and their GP were affiliated with a CPAM of mainland Départements not covered by the program (i.e., the unexposed).

The geographical areas chosen for the pilot experiment cover a population of approximately 168,000 subjects meeting the aforementioned eligibility criteria. This population was not chosen to be strictly representative of all asthmatic patients in France.

\section{Study design}

This evaluation study was designed as a prospective, non-randomized, matched controlled, quasi-experimental before-and-after study. ${ }^{9}$ We defined three periods: (i) 1 January 2014 31 December 2014: the 12-month "before program implementation" period, (ii) 1 January 2015 - 28 February 2015: the implementation period, and (iii) 1 March 2015 - 29 February 2016: the 12-month "after program implementation" period. The exposed group (intervention group) was composed of individuals targeted by SA program. The unexposed group was composed of matched individuals meeting eligibility criteria of the intervention group except they and their GP were affiliated with CPAM of mainland Départements not covered by the program. Each subject from the intervention group was matched with an 
unexposed, by stratification variables (asthma-related hospital stay in the last 12 months (yes vs. no), the number of asthma drug deliveries in the last 12 months ( 2 vs. $\geq 3$ ) and age at program enrollment $(<40$ vs. $\geq 40)$ ), and by the propensity score of being exposed. ${ }^{10-12}$ We report our findings in accordance with The Reporting Quality of Non Randomized Evaluations of Behavioral and Public Health Interventions (TREND) statement. ${ }^{13}$

\section{Outcome measures}

The outcomes were extracted from the SNDS database in 2015 and match the desired effects of the intervention: improved asthma control, improved adherence to controller asthma medications, improved use of healthcare resources, reduced exacerbations and days off work.

The primary outcome of interest relied on an asthma medication ratio measuring the proportion of controllers out of total asthma therapy (i.e., controllers and relievers) over a given study period. ${ }^{14}$ More precisely, it is the ratio of inhaled corticosteroid (ICS) (whether in fixed combination with long-acting $\beta$-agonists (LABAs) or not) plus leukotriene receptor antagonist (LTRA) to total asthma medications (R03 according to ATC classification, Appendix 1). In this study, the primary outcome was a high ICS+LTRA/R03 ratio (i.e., $\geq 50 \%$ ), which has been shown in claims data to be associated with fewer asthma-related hospitalizations, fewer emergency room (ER) visits, ${ }^{14}$ and better patient-centered asthma outcomes (such as asthma quality of life and symptoms severity). ${ }^{15}$ The secondary outcomes included asthma exacerbations (defined as asthma-related hospitalization, asthma -related ER visit or visit to the GP with a dispensation of systemic corticosteroids within seven days of the GP visit), urgent care visits (asthma-related ER room visits and hospitalizations, GP visits for asthma exacerbations), routine asthma visits (GP visits for asthma- defined as dispensation of R03 drugs within seven days of the GP visit-, pulmonologist visits, and pulmonary function 
testing), dispensation of at least one controller medication, dispensation of four or more SABA, sustained use of controller medications (defined as five or more dispensations of ICS in fixed association with LABA or not- or eight or more units of LTRA), adherence to asthma controller medication (ICS alone or in fixed combination with LABA) as measured by the Medication Refill Adherence (MRA), ${ }^{16}$ and work absenteeism as measured by the number of sick leave days related to asthma (Appendix 2).

\section{Data sources}

This study was undertaken using a database formed by linking the SNDS ${ }^{17}$ database and SA program database, which only included the program participants (questionnaire administered upon entry into the study, and program operational data).

In France, the SNDS compiles data from the French National Health Insurance System (including the national hospital-discharge summaries database system - PMSI). ${ }^{18}$ Information on healthcare reimbursement, ambulatory and hospital expenditures data, as well as sociodemographics including age, gender, French administrative area of residence, advantage of the Complementary Universal Health Coverage (CMU-C, an individual measure of low socioeconomic position (SEP)), and long-term chronic disease status allowing for full medical reimbursement, is available in the SNDS. Data obtained for subjects included in our study comprise sociodemographic and outpatient reimbursed health visits and drugs (coded with ATC classification) on the one hand, and the dates of start and end of hospital stays, with diagnostic codes (primary, related and associated diagnoses coded with the International Information Classification of Diseases, version ICD-10), ${ }^{19}$ and most of costly procedures (Classification commune des actes médicaux, CCAM), ${ }^{20}$ on the other hand. The study funder and commissioner (National Health Insurance Fund) undertook the linkage between SNDS records and the information collected within SA program. According to the 
law ( ${ }^{\circ} 2016-41$, JORF 2016), a permanent access to SNDS is granted to CNAM employees, but also to subcontractor acting under the authority of CNAM, under very strict conditions (accreditations, secure access...). The statistician authors, as subcontractors to CNAM, had complete and free access to the database. This evaluation is covered by the law of the 6th January 1978 and the decree $n{ }^{\circ}$ 2012-1249 of the 9th November 2012 authorizing the creation of personal data processing for the implementation of health prevention and support programs for insured persons. The data processing was the subject of a commitment of conformity to the aforementioned decree.

\section{Power calculation}

The a priori power calculation was based on a $5 \%$ increase in the proportion of patients with a ratio $\mathrm{ICS}+\mathrm{LTRA} / \mathrm{R} 03 \geq 50 \%$ among program participants and their matched unexposed subjects in the intervention group. Assuming 160,000 subjects in the exposed group and a rate of $10 \%$ of program participation, we reached a power of $80 \%$ with a $5 \%$ two-tailed test.

\section{Statistical methods}

We generated a propensity score with all the subjects, for matching subjects of the intervention (exposed) and unexposed groups within each stratum (caliper=0.20). The probability of being exposed to the program was modeled using a multivariate logistic regression including the following covariates: age, sex, average number of units of the ATC R03 class delivered over the years 2012, 2013 and 2014, CMU-C, prevalence of asthma in the area of residence, as well as characteristics of the geographic location of GP practice (Rey deprivation index, ${ }^{21}$ which is an area-level measure of SEP, the medical density, the size, and the rural or urban character). ${ }^{22}$ The prevalence of asthma reflects in an integrated and pragmatic way the factors that trigger asthma exacerbations (such as atmospheric 

survey of adults in France (Enquête santé protection sociale -ESPS) ${ }^{23}$ and a national school

223 health survey. ${ }^{24,25}$ We used standardized mean differences and histograms, for analyzing balance in measured baseline variables before and after matching. After propensity-score

conditions, weather conditions, pollination, influenza, etc.); it was derived from a national matching, we compared differences in patient's outcomes using the difference-indifferences (DiD) analysis approach. We compared the change in outcomes in subjects of the intervention group between the "before program implementation" period and the "after program implementation" period with the change of outcomes in subjects of the unexposed group within the same time period, by use of linear mixed models and generalized mixed models for testing the effect of the program on continuous and dichotomous outcomes, respectively.

We conducted subgroup analyses to focus on populations in which the probability to be asthmatic was higher than in the whole study population: (i) patients with at least three different reimbursement dates of R03 in 2013 (a priori subgroup analysis), (ii) patients with at least one reimbursement date of R03 in 2012, and (iii) patients with more stringent criteria for the definition of asthma (algorithm developed by the CNAM: subjects with $\geq 1$ IgE antagonist or $\geq 1$ xanthine or $\geq 1$ LTRA (alone or with ICS) or $\geq 3$ ICS-LABA or $\geq 3$ ICS or $\geq 3$ LABA or $\geq 3$ SABA are considered asthmatic).

All analyses were conducted using SAS guide 9.3 (SAS Institute, Cary NC) and R version 3.1.1. R Core Team (2014). ${ }^{26}$ A level of a two-tailed statistical significance of $p<0.05$ was used for all statistical tests performed. 


\section{RESULTS}

\section{Baseline characteristics}

In January $2015,108,053$ subjects were targeted by SA program. Of those, 105,957 were eligible to the intervention group of the study (Figure 1). After matching, 199,156 individuals were included in the study, with 99,578 in each group. The quality of propensity matching is graphically displayed in Supplemental Figures S1A and S1B (Appendix 3). Mean age ( \pm SD) was $34( \pm 7)$ years (IQR 29-41). Women and CMU-C recipients constituted respectively $60 \cdot 3 \%$ and $19.5 \%$ of the study population (Table 1 ). This population was characterized by features suggesting poor asthma control (less than half of them had an ICS+LTRA/R03 drug ratio $\geq 0 \cdot 5$, one third of them exhibited at least one asthma exacerbation during the previous year) and little adherence to treatment $(7 \cdot 1 \%$ had a MRA $>80 \%)$ ) (Table 2$)$. A small proportion (11\%) of them consulted a lung specialist and about a half received ICS (alone or in combination with LABA) during the year preceding the program.

\section{Description of Sophia Asthme program outputs}

In the intervention group, 9,225 (9.3\%) subjects actually participated in the program. Mean number telephone calls was 1·8. Fifty-four percent of the participants had "low-intensity intervention"; $30.4 \%$ and $15.6 \%$ had "moderate-intensity" and "high-intensity intervention", respectively.

The written support provided was the same for all participants, but only those who communicated their e-mail address $(58.8 \%)$ received the e-newsletters. Among them, the majority received four or five e-newsletters $(18.9 \%$ and $31.8 \%$ of the participants, respectively). The majority of the participants (80.6\%) received three leaflets; $16 \cdot 2 \%$ received two leaflets. 
266

267

268

269

270

271

272

273

Table 2 presents the evolution of outcomes before and after program implementation. Most indicators decreased over time in both the intervention and the unexposed group, indicating a period effect. From the "before program implementation" period to the "after program implementation" period, the proportion of subjects with a high ICS+LTRA/R03 decreased in both groups by $4.9 \%$. No significant difference was observed for other asthma control or for medication adherence indicators. However, the effect of SA program was significant in terms of more frequent patients with at least one controller medication prescription dispensed (OR $=1.04 ; 95 \% \mathrm{Cl}, 1.01$ to 1.07$)$, with sustained use of controller medications $(\mathrm{OR}=1.08 ; 95 \% \mathrm{Cl}$, 1.05 to 1.12$)$, and with higher total number of R03 prescriptions dispensed $(\beta=0.36 ; 95 \% \mathrm{Cl}$, 0.25 to 0.47$)$ in the intervention group..

\section{Subgroup analyses}

The results were similar for patients with three or more R03 prescriptions dispensed in the last 12 months prior to program targeting (in 2013), but the program effect size was relatively larger on the total number of R03 prescriptions dispensed $(\beta=0.51 ; 95 \% \mathrm{Cl}, 0.35$ to $\mathbf{0 6 7 )}$. The comparison of program participants to their matched unexposed showed larger effects sizes on the sustained use of controller medications (OR $=1 \cdot 29 ; 95 \% \mathrm{Cl}, 1 \cdot 16$ to 1.43 ) and on the total number of R03 prescriptions dispensed $(\beta=0.76 ; 95 \% \mathrm{Cl}, 0 \cdot 36$ to $1 \cdot 16)$. In addition, this subgroup analysis revealed a significant protective effect of the program on the risk of asthma exacerbations $(\mathrm{OR}=0.90 ; 95 \% \mathrm{Cl}, 0.83$ to 0.99$)$ and a significant decrease in the number of asthma-related sickleave days $(\beta=-0.33 ; 95 \% \mathrm{Cl},-0.59$ to -0.07$)$ (Table 2$)$. Results were similar in the people with asthma according to the CNAM algorithm (Table 3). 
288

In this paper, we have examined the early impact of an asthma disease management program in France, SA. The study did not achieve its primary objective, which was to demonstrate an increase in the proportion of patients with a high ICS+LTRA/R03 ratio in the intervention group. Additionally, there was no evidence that the program reduced the risk of asthma-related hospitalizations, ER visits for acute asthma, and asthma exacerbations. However, the program was found to be associated with an increase in the dispensation of R03, the proportion of subjects with dispensation of at least one controller medication, and the sustained use of controller medications. Furthermore, in subgroup analyses focusing on people more likely to be asthmatic, the impact of the program was significant for some asthma treatment-related outcomes (R03 prescriptions dispensed, at least one controller medication prescription dispensed, sustained use of controller medications), and some clinical outcomes (asthma exacerbations, number of asthma-related sickleave days).

These results can be interpreted as an absence of impact of the SA program. However, alternative explanations must be discussed. First, the (two months') duration of the implementation period was not sufficiently long to translate into better asthma outcomes. Chronic conditions require long-lasting interventions to promote health behavior changes, such as motivation for medication adherence, smoking cessation, and risk reduction strategies (avoidance of triggers and pollutants). Clinical changes may have occurred outside the timeframe of the observation period. There was an improvement in the use of controller medications (which is a process indicator), we would therefore expect a decrease in asthma exacerbation over a longer time span. Second, the study was underpowered. The initial power calculation was based on the best available data, and suggested that 160000 patients targeted by the program with a participation rate of $10 \%$ would give $80 \%$ power to detect a 
$5 \%$ increase in the primary outcome among SA participants. Unfortunately, the number of individual eligible to the program and the participation rate were smaller than anticipated.

The low uptake of the intervention may be due to early assessment (some people may have started to participate after the implementation period). It could also be due to suboptimal

targeting of patients diagnosed with asthma: the algorithm used to target the population (at least two deliveries of R03 over the last 12 months) was probably not specific enough, stressing the need for a more specific targeting of the SA program. Third, the population was mainly of low severity asthma, with only $3.7 \%$ with LTD status for severe asthma, and $0.36 \%$ with an asthma-related hospitalization in 2014. Thus the room for improvement on severe outcomes as hospitalization was very small. Hence, we performed a priori and post-hoc subgroup analysis, so that the captured population better matches the population of interest. These analysis generated results congruent with the primary analysis, but relatively larger and significant positive effects were observed for some of the secondary treatment-related and clinically relevant outcomes (including asthma exacerbations and sickleave days). Fourth, the participation rate to the SA program was low at this early evaluation, inducing a dilution effect. Fifth, we cannot exclude that the program lacked of a component primarily targeting healthcare professionals (e.g., physician education and training). The use of written personalized action-plan for self-management support may also have been missing. According to the literature, even in countries that have been proactive about recommending asthma self-management, three quarters of asthmatic patients are not provided with written action plans. ${ }^{27,28}$ Finally, our findings are consistent with the literature indicating overall small effects and no effect on ER visits. ${ }^{6,29}$

Major strengths of this study include the use of routinely collected health data and the large number of geographical areas involved, allowing a very good external validity of the results; 
the large sample size, enabling precise effect size estimates; and the relevance of outcomes assessed. In particular, effects on asthma exacerbations and days off work are typically insufficiently reported in studies evaluating asthma management programs, according to the Cochrane systematic review published recently by Peytremann-Bridevaux and colleagues. ${ }^{27}$ Keeping in line with their recommendations, we assessed process of care indicators (e.g., MRA rate for controller medications, dispensation of controller medications) and healthcare utilization indicators (e.g., routine GP visits, ER visits) to better interpret the outcomes results at the patient-level.

However, some limitations should be considered when interpreting the results of this study. First, the design of the evaluation was performed after the implementation perimeter was planned by the CNAM means that it was not possible to randomly assign patients to the intervention and control groups nor to promote a more focused target population. We used, as recommended in such cases, ${ }^{30}$ a controlled before-and-after quasi-experimental design with matching on stratification variables and propensity score. Quasi-experimental studies (where individuals are not randomly allocated) ${ }^{30}$ include some attempt to limit or control threats to internal validity but we cannot exclude the possibility of a residual confounding bias Second, in healthcare databases, outcomes are usually addressed by use of proxies, which can induce measurement errors. However, we used proxies similar to those used in other studies, and, by design, these measurement errors are not differential, thus can only bias towards the null. Third, as stated above, the study was underpowered. The a posteriori power (keeping the initial assumptions) in the light of observed numbers is of $52 \%$ to detect a difference of $5 \%$ among the program participants and matched unexposed people (corresponding to a difference of $0.4 \%$ for the whole study population). Here we had a power of $80 \%$ to detect in the program participants a difference of $7 \%$ ( $0.6 \%$ for the whole study population) 
360 In conclusion, SA program piloting phase was not associated with a significant effect at this

361 early phase evaluation on the primary outcome, the ICS+LTRA/R03 ratio. It had a modest

362 impact on some secondary outcomes, particularly on specific subgroups of patients more

363 likely to be asthmatic, leaving open the possibility that suboptimal targeting of the 364 population undermined the evaluation of the program effectiveness.

365 Our results can help the CNAM making informed decisions about whether and how to 366 continue to support this program, by improving the targeting of the population and 367 considering reformulation of the program followed by a subsequent evaluation.

\section{ACKNOWLEDGEMENTS}

369 This study was commissioned and funded by the Caisse Nationale d'Assurance Maladie 370 (CNAM), Paris, France. The CNAM did not have any role in the trial design, data analysis and 371 interpretation, the writing of the manuscript and the decision to submit it for publication.

372 However, they were in charge of data collection (as we used the French claims database and 373 some data from the Sophia Asthme program run by the CNAM). 


\section{REFERENCES}

1 Raherison C, Bourdin A, Bonniaud P, et al. Updated guidelines (2015) for management and monitoring of adult and adolescent asthmatic patients (from 12 years and older) of the Société de Pneumologie de Langue Française (SPLF) (Full length text). Rev Mal Respir 2016; 33: 279-325.

2 To T, Stanojevic S, Moores G, et al. Global asthma prevalence in adults: findings from the cross-sectional world health survey. BMC Public Health 2012; 12: 204.

3 WHO | Asthma. WHO. http://www.who.int/mediacentre/factsheets/fs307/en/ (accessed Feb 28, 2018).

4 Demoly P, Paggiaro P, Plaza V, et al. Prevalence of asthma control among adults in France, Germany, Italy, Spain and the UK. Eur Respir Rev Off J Eur Respir Soc 2009; 18: 105-12.

5 Fuhlbrigge A, Reed ML, Stempel DA, Ortega HO, Fanning K, Stanford RH. The status of asthma control in the U.S. adult population. Allergy Asthma Proc 2009; 30: 529-33.

6 Peytremann-Bridevaux I, Arditi C, Gex G, Bridevaux P-O, Burnand B. Chronic disease management programmes for adults with asthma. Cochrane Database Syst Rev 2015; : CD007988.

7 sophia, le service d'accompagnement de l'Assurance Maladie | ameli.fr. https://www.ameli.fr/assure/sante/assurance-maladie/sophia/service-sophia-assurancemaladie (accessed Feb 28, 2018).

8 Bateman ED, Hurd SS, Barnes PJ, et al. Global strategy for asthma management and prevention: GINA executive summary. Eur Respir J 2008; 31: 143-78.

913 Including non-randomized studies. http://handbook-51.cochrane.org/chapter_13/13_including_non_randomized_studies.htm (accessed Feb 28, 2018).

10 Rubin DB. Estimating causal effects from large data sets using propensity scores. Ann Intern Med 1997; 127: 757-63.

11 Little RJ, Rubin DB. Causal effects in clinical and epidemiological studies via potential outcomes: concepts and analytical approaches. Annu Rev Public Health 2000; 21: 121-45.

12 Linden A, Adams JL, Roberts N. Using Propensity Scores to Construct Comparable Control Groups for Disease Management Program Evaluation: Dis Manag Health Outcomes 2005; 13: 107-15.

13TREND statement | CDC. https://www.cdc.gov/trendstatement/ (accessed April 17, 2017).

14 Laforest L, Licaj I, Devouassoux G, Chatte G, Martin J, Ganse EV. Asthma drug ratios and exacerbations: claims data from universal health coverage systems. Eur Respir J 2014; 43: 1378-86. 
15 Schatz M, Zeiger RS, Vollmer WM, et al. The controller-to-total asthma medication ratio is associated with patient-centered as well as utilization outcomes. Chest 2006; 130: 43-50.

16 Hess LM, Raebel MA, Conner DA, Malone DC. Measurement of adherence in pharmacy administrative databases: a proposal for standard definitions and preferred measures. Ann Pharmacother 2006; 40: 1280-8.

17 Palmaro A, Moulis G, Despas F, Dupouy J, Lapeyre-Mestre M. Overview of drug data within French health insurance databases and implications for pharmacoepidemiological studies. Fundam Clin Pharmacol 2016; 30: 616-24.

18Tuppin $\mathrm{P}$, Rudant J, Constantinou $\mathrm{P}$, et al. Value of a national administrative database to guide public decisions: From the système national d'information interrégimes de I'Assurance Maladie (SNIIRAM) to the système national des données de santé (SNDS) in France. Rev Epidemiol Sante Publique 2017; 65 Suppl 4: S149-67.

19WHO | International Classification of Diseases. WHO. http://www.who.int/classifications/icd/en/ (accessed Feb 28, 2018).

20 Moulis G, Lapeyre-Mestre M, Palmaro A, Pugnet G, Montastruc J-L, Sailler L. French health insurance databases: What interest for medical research? Rev Med Interne 2015; 36: 4117.

21 Rey G, Jougla E, Fouillet A, Hémon D. Ecological association between a deprivation index and mortality in France over the period 1997 - 2001: variations with spatial scale, degree of urbanicity, age, gender and cause of death. BMC Public Health 2009; 9: 33.

22Statistiques | Insee.

https://www.insee.fr/fr/statistiques?debut=0\&theme=69\&geo=FRANCE-1 (accessed March 1, 2018).

23 Résumé rapport 1820. IRDES. Institut de Recherche en Economie de la santé. http://www.irdes.fr/EspaceRecherche/BiblioResumeEtSommaire/2011/Rapport1820.htm (accessed March 1, 2018).

24Guignon N, Collet M, Gonzalez L. La santé des enfants en grande section de maternelle en 2005-2006. Études et Résultats, DREES 2010, nº 737.

25 de Saint Pol Th. Les inégalités géographiques de santé chez les enfants de grande section de maternelle. $\mathrm{BE} \mathrm{H} 2011, \mathrm{n}^{\circ} 31$.

26R: The R Project for Statistical Computing. https://www.r-project.org/ (accessed March 1, 2018).

27 Wiener-Ogilvie S, Pinnock H, Huby G, Sheikh A, Partridge MR, Gillies J. Do practices comply with key recommendations of the British Asthma Guideline? If not, why not? Prim Care Respir J J Gen Pract Airw Group 2007; 16: 369-77. 
28Sulaiman N, Aroni R, Thien F, et al. Written Asthma Action Plans (WAAPs) in Melbourne general practices: a sequential mixed methods study. Prim Care Respir J J Gen Pract Airw Group 2011; 20: 161-9, 1 p following 169.

29Lemmens KMM, Nieboer AP, Huijsman R. A systematic review of integrated use of disease-management interventions in asthma and COPD. Respir Med 2009; 103: 670-91.

30 anonymous. EPOC-specific resources for review authors | Cochrane Effective Practice and Organisation of Care. http://epoc.cochrane.org/epoc-specific-resources-review-authors (accessed March 21, 2016). 
TABLES

Table 1. Characteristics of the included subjects during the "before program" period, across groups: Sophia Asthme Program intervention (with program participants and non-participants) and matched unexposed groups.

\begin{tabular}{|c|c|c|c|c|c|}
\hline \multirow[t]{2}{*}{ Variables } & \multicolumn{3}{|c|}{ Intervention (i.e. exposed) group } & \multirow[b]{2}{*}{ P value } & \multirow[t]{2}{*}{ Unexposed group } \\
\hline & Total & Program participants & $\begin{array}{l}\text { Program non- } \\
\text { participants }\end{array}$ & & \\
\hline No. of subjects & 99,578 & 9,226 & 90,353 & & 99,578 \\
\hline \multicolumn{6}{|l|}{ Demographics } \\
\hline Age (years), mean (SD) & $34 \cdot 40(7 \cdot 25)$ & $35 \cdot 32(7 \cdot 18)$ & $34 \cdot 30(7 \cdot 25)$ & $<0.0001$ & $34 \cdot 22(7 \cdot 45)$ \\
\hline Female & $60,076(60 \cdot 33 \%)$ & $5,837(63 \cdot 27 \%)$ & $54,240(60 \cdot 03 \%)$ & $<0.0001$ & $60,454(60 \cdot 71 \%)$ \\
\hline CMU-C* recipient & $19,366(19 \cdot 45 \%)$ & $1,968(21 \cdot 33 \%)$ & $17,398(19 \cdot 26 \%)$ & $<0.0001$ & $20,819(20 \cdot 91 \%)$ \\
\hline \multicolumn{4}{|c|}{$\begin{array}{l}\text { Rey deprivation index (unweighted) quintiles of the municipality where } \\
\text { the GP is professionally based }\end{array}$} & $<0.0001$ & \\
\hline $1^{\text {st }}$ quintile & $26,828(26 \cdot 94 \%)$ & $2,369(25 \cdot 68 \%)$ & $24,459(27 \cdot 07 \%)$ & & $24,474(24 \cdot 58 \%)$ \\
\hline $2^{\text {nd }}$ quintile & $20,107(20 \cdot 19 \%)$ & $1,847(20 \cdot 02 \%)$ & $18,260(20 \cdot 21 \%)$ & & $20,102(20 \cdot 19 \%)$ \\
\hline $3^{\text {rd }}$ quintile & $14,803(14 \cdot 87 \%)$ & $1,310(14 \cdot 20 \%)$ & $13,493(14 \cdot 93 \%)$ & & $14,633(14 \cdot 70 \%)$ \\
\hline $4^{\text {th }}$ quintile & $14,963(15 \cdot 03 \%)$ & $1,408(15 \cdot 26 \%)$ & $13,556(15 \cdot 00 \%)$ & & $15,391(15 \cdot 46 \%)$ \\
\hline $5^{\text {th }}$ quintile & $22,877(22 \cdot 97 \%)$ & $2,292(24 \cdot 84 \%)$ & $20,585(22 \cdot 78 \%)$ & & $24,978(25 \cdot 08 \%)$ \\
\hline $\begin{array}{l}\text { Geographic location of } \\
\text { GP } \\
\text { Rural (vs Urban) }\end{array}$ & $10,223(10 \cdot 27 \%)$ & $843(9 \cdot 14 \%)$ & $9,380(10 \cdot 38 \%)$ & 0.0002 & $10,951(11 \cdot 00 \%)$ \\
\hline \multicolumn{6}{|l|}{ Clinical } \\
\hline $\begin{array}{l}\text { Long-term chronic } \\
\text { disease status for } \\
\text { severe asthma in } 2014\end{array}$ & $3,706(3 \cdot 72 \%)$ & $570(6 \cdot 18 \%)$ & $3,136(3 \cdot 47 \%)$ & $<0.0001$ & $6,428(6 \cdot 46 \%)$ \\
\hline
\end{tabular}




\begin{tabular}{|c|c|c|c|c|c|}
\hline (or before) & & & & & \\
\hline $\begin{array}{l}\text { Asthma-related } \\
\text { hospitalization in } 2014\end{array}$ & $355(0 \cdot 36 \%)$ & $82(0 \cdot 89 \%)$ & $273(0 \cdot 30 \%)$ & $<0.0001$ & $355(0 \cdot 36 \%)$ \\
\hline \multicolumn{6}{|l|}{ No. of R03 medications } \\
\hline $\begin{array}{l}\text { No. of R03 prescription } \\
\text { dispensed during the } \\
\text { "before program } \\
\text { implementation" } \\
\text { period, mean (SD) }\end{array}$ & $4 \cdot 46(3 \cdot 03)$ & $4 \cdot 87(3 \cdot 04)$ & $4 \cdot 41(3 \cdot 02)$ & $<0.0001$ & $6 \cdot 10(4 \cdot 71)$ \\
\hline $\begin{array}{l}\text { No. of R03 prescriptions } \\
\text { dispensed in 2012, } \\
\text { mean (SD) }\end{array}$ & $7 \cdot 74(6 \cdot 08)$ & $8.56(5.94)$ & $7 \cdot 66(6 \cdot 08)$ & $<0.0001$ & $5 \cdot 39(5 \cdot 18)$ \\
\hline
\end{tabular}

Data are no. (\%) of patients, unless otherwise indicated.

*CMU-C, complementary universal health coverage. 
Table 2. Change in outcomes form the "before program implementation" period to the "after program implementation" period: a) for patients in the intervention (i.e. exposed) and unexposed groups, b) for program participants and their matched unexposed

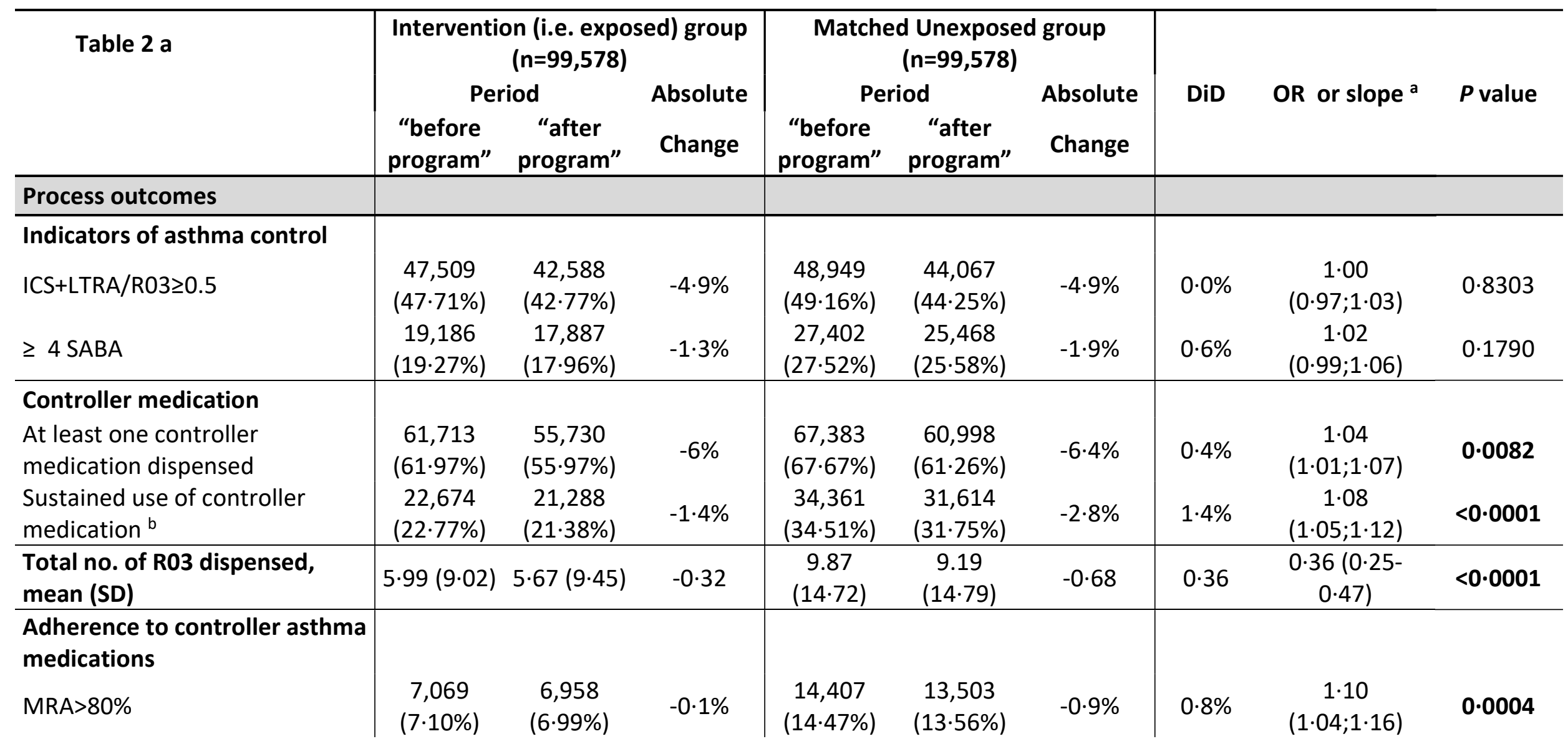




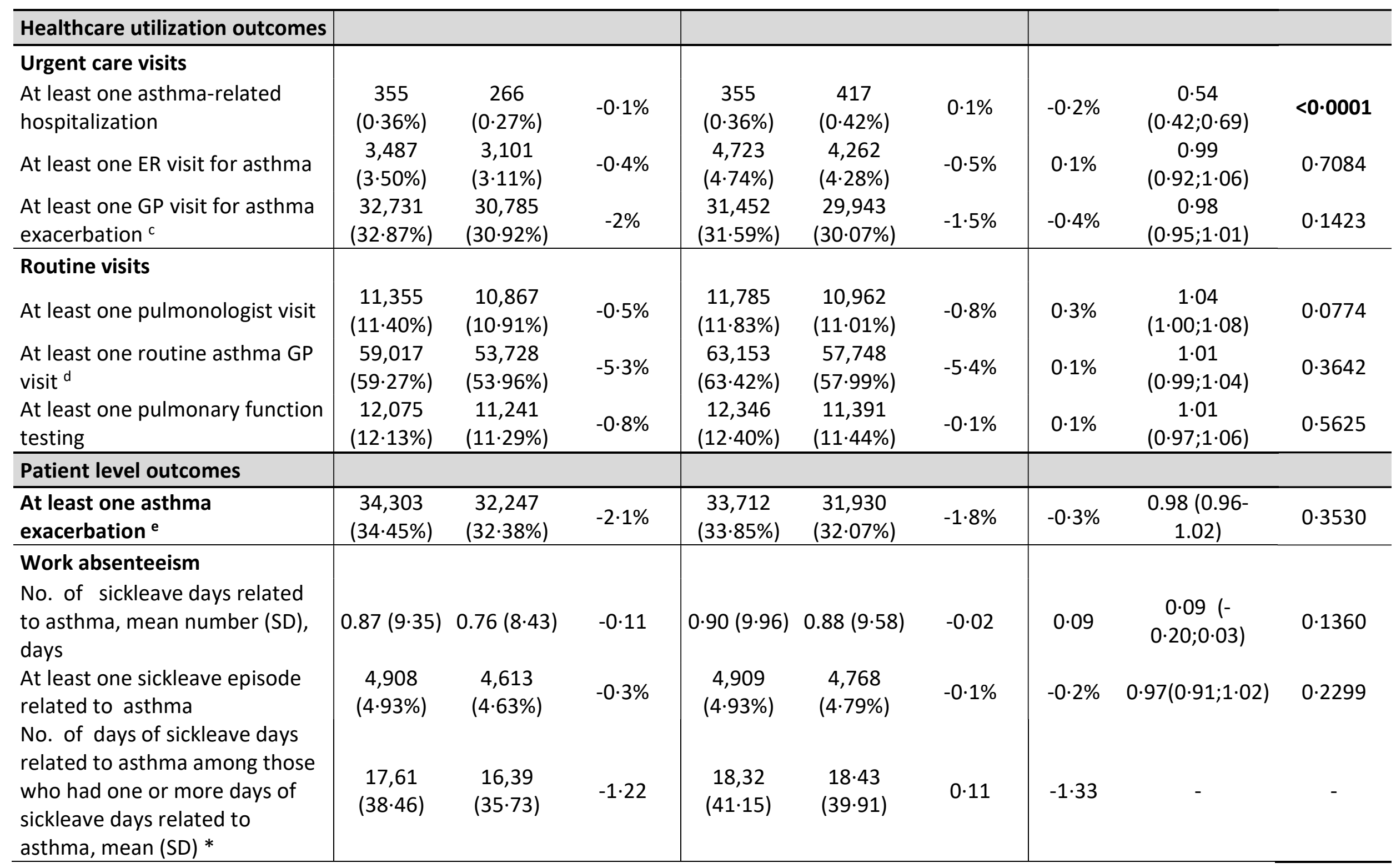




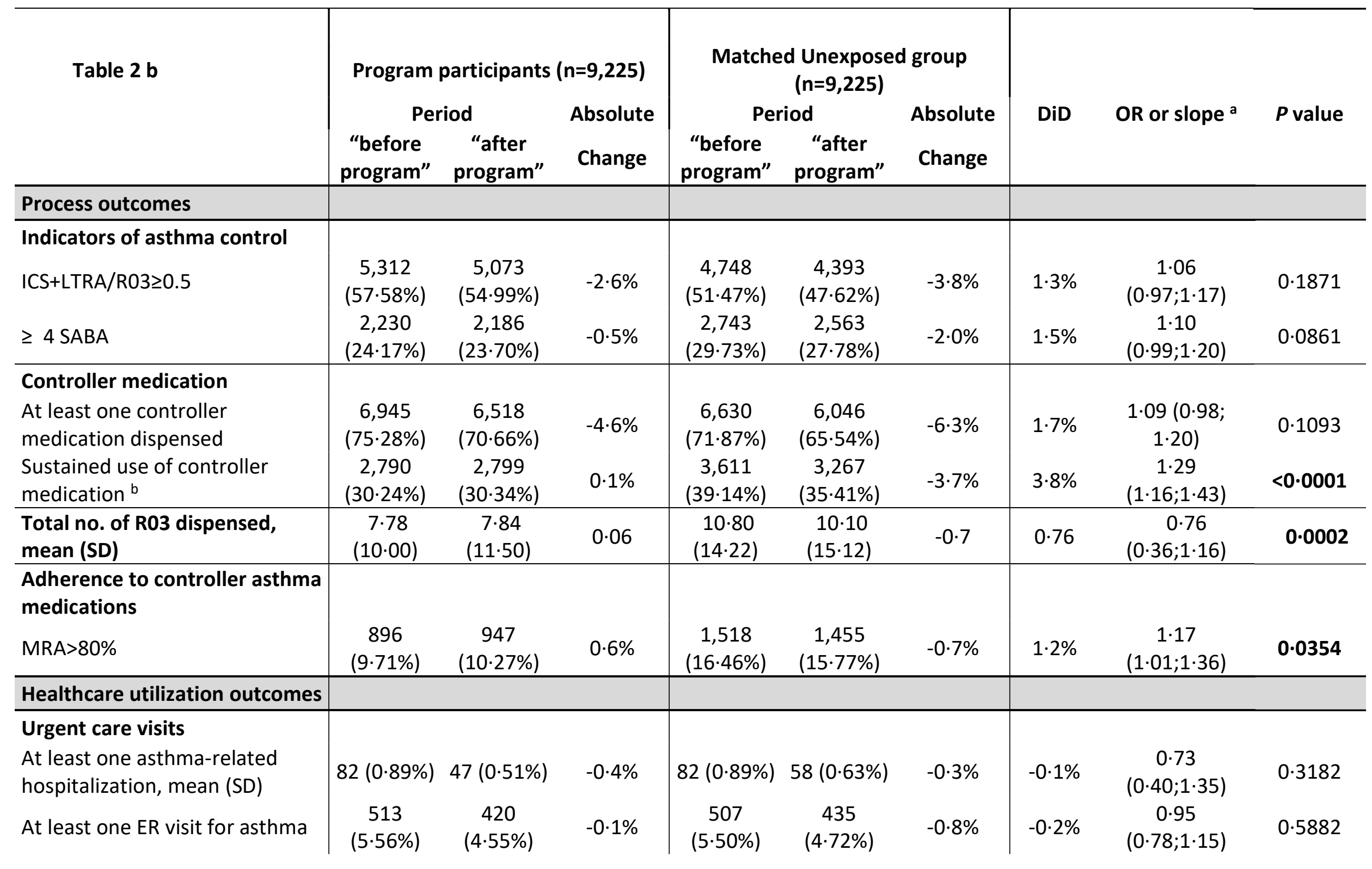




\begin{tabular}{|c|c|c|c|c|c|c|c|c|c|}
\hline $\begin{array}{l}\text { At least one GP visit for asthma } \\
\text { exacerbation }{ }^{c}\end{array}$ & $\begin{array}{c}3,408 \\
(36 \cdot 94 \%) \\
\end{array}$ & $\begin{array}{c}3,087 \\
(33 \cdot 46 \%) \\
\end{array}$ & $-3 \cdot 5 \%$ & $\begin{array}{c}2,942 \\
(31 \cdot 89 \%) \\
\end{array}$ & $\begin{array}{c}2,828 \\
(30 \cdot 66 \%) \\
\end{array}$ & $-1 \cdot 2 \%$ & $-2 \cdot 2 \%$ & $\begin{array}{c}0.90 \\
(0 \cdot 82 ; 0 \cdot 99)\end{array}$ & 0.0229 \\
\hline \multicolumn{10}{|l|}{ Routine visits } \\
\hline At least one pulmonologist visit & $\begin{array}{c}1,685 \\
(18 \cdot 27 \%)\end{array}$ & $\begin{array}{c}2,067 \\
(22 \cdot 41 \%)\end{array}$ & $4 \cdot 1 \%$ & $\begin{array}{c}1,181 \\
(12 \cdot 80 \%)\end{array}$ & $\begin{array}{c}1,141 \\
(12 \cdot 37 \%)\end{array}$ & $-0 \cdot 4 \%$ & $4 \cdot 6 \%$ & $\begin{array}{c}1 \cdot 41 \\
(1 \cdot 25 ; 1 \cdot 59)\end{array}$ & $<0.0001$ \\
\hline $\begin{array}{l}\text { At least one routine asthma GP } \\
\text { visit d }\end{array}$ & $\begin{array}{c}6,551 \\
(71 \cdot 01 \%)\end{array}$ & $\begin{array}{c}6,062 \\
(65 \cdot 71 \%)\end{array}$ & $-5 \cdot 3 \%$ & $\begin{array}{c}6,122 \\
(66 \cdot 36 \%)\end{array}$ & $\begin{array}{c}5,626 \\
(60 \cdot 99 \%)\end{array}$ & $-5 \cdot 4 \%$ & $0 \cdot 1 \%$ & $\begin{array}{c}0.99 \\
(0.90 ; 1 \cdot 08)\end{array}$ & $0 \cdot 7870$ \\
\hline $\begin{array}{l}\text { At least one pulmonary function } \\
\text { testing }\end{array}$ & $\begin{array}{c}1,716 \\
(18 \cdot 60 \%) \\
\end{array}$ & $\begin{array}{c}2,091 \\
(22 \cdot 67 \%) \\
\end{array}$ & $4 \cdot 1 \%$ & $\begin{array}{c}1,233 \\
(13 \cdot 37 \%) \\
\end{array}$ & $\begin{array}{c}1,186 \\
(12 \cdot 86 \%) \\
\end{array}$ & $-0 \cdot 5 \%$ & $4 \cdot 6 \%$ & $\begin{array}{c}1 \cdot 40 \\
(1 \cdot 25 ; 1 \cdot 58) \\
\end{array}$ & $<0.0001$ \\
\hline \multicolumn{10}{|l|}{ Patient level outcomes } \\
\hline $\begin{array}{l}\text { At least one asthma } \\
\text { exacerbation } \text { e }^{\text {exace }}\end{array}$ & $\begin{array}{c}3643 \\
(39 \cdot 49 \%)\end{array}$ & $\begin{array}{c}3267 \\
(35 \cdot 41 \%) \\
\end{array}$ & $-4 \cdot 1 \%$ & $\begin{array}{c}3193 \\
(34 \cdot 61 \%)\end{array}$ & $\begin{array}{c}3019 \\
(32 \cdot 73 \%)\end{array}$ & $-1 \cdot 9 \%$ & $-2 \cdot 2 \%$ & $\begin{array}{c}0.90 \\
(0.83 ; 0.99)\end{array}$ & 0.0289 \\
\hline \multicolumn{10}{|l|}{ Work absenteeism } \\
\hline $\begin{array}{l}\text { No. of sickleave days related } \\
\text { to asthma, mean number (SD), } \\
\text { days }\end{array}$ & $\begin{array}{c}1 \cdot 21 \\
(10 \cdot 73)\end{array}$ & $0.91(8 \cdot 78)$ & $-0 \cdot 30$ & $\begin{array}{c}1 \cdot 07 \\
(11 \cdot 31)\end{array}$ & $\begin{array}{c}1 \cdot 10 \\
(11 \cdot 50)\end{array}$ & 0.03 & $-0 \cdot 33$ & $\begin{array}{c}-0.33(-0 \cdot 59 ;- \\
0 \cdot 07)\end{array}$ & 0.0119 \\
\hline $\begin{array}{l}\text { At least one sickleave episode } \\
\text { related to asthma }\end{array}$ & $\begin{array}{c}547 \\
(5 \cdot 93 \%)\end{array}$ & $\begin{array}{c}479 \\
(5 \cdot 19 \%)\end{array}$ & $-0 \cdot 7 \%$ & $\begin{array}{c}480 \\
(5 \cdot 20 \%)\end{array}$ & $\begin{array}{c}497 \\
(5 \cdot 39 \%)\end{array}$ & $0 \cdot 2 \%$ & $-0 \cdot 9 \%$ & $\begin{array}{c}0.83 \\
(0.69 ; 0.99)\end{array}$ & 0.0463 \\
\hline $\begin{array}{l}\text { No. of days of sickleave days } \\
\text { related to asthma among those } \\
\text { who had one or more days of } \\
\text { sickleave days related to } \\
\text { asthma, mean (SD) * }\end{array}$ & $\begin{array}{c}20 \cdot 39 \\
(39 \cdot 39)\end{array}$ & $\begin{array}{c}17 \cdot 52 \\
(34 \cdot 57)\end{array}$ & $-2 \cdot 87$ & $\begin{array}{c}20 \cdot 49 \\
(45 \cdot 41)\end{array}$ & $\begin{array}{c}20 \cdot 41 \\
(45 \cdot 42)\end{array}$ & -0.08 & $-2 \cdot 79$ & - & - \\
\hline
\end{tabular}

Data are no. (\%) of patients, unless otherwise indicated. Values in bold indicate significant associations $(p<0.05)$.

DiD, difference-in-differences (change in outcomes in exposed minus change in outcomes in the unexposed: if the DiD is positive, it means the increase in the variable is higher in the exposed vs unexposed); ER, emergency room; ICS, inhaled corticosteroids; LTRA, leukotriene receptor antagonist; MRA, medication refill adherence; GP, general practitioner; SABA, short-acting $\beta$-agonist; LABA, long-acting $\beta$-agonist.

a The following equation was used: $Y i=\beta O+\beta 1$ INTERVENTION $+\beta 2$ PERIOD $+\beta 3$ (INTERVENTION X PERIOD) + ei 
where $\mathrm{Yi}$ is the value of the dependent variable for the $\mathrm{i}$ th patient, INTERVENTION is a dummy variable representing exposition to the program (INTERVENTION=1), PERIOD is a dummy variable ( $0=$ "before program implementation" period and $1=$ "after program implementation"

period). The coefficient of the interaction term ( $\beta 3$ ) reflects the impact of the program).

${ }^{b}$ Defined as five or more units of ICS/LABA in a single inhaler and/or ICS as a single agent medicine, or 8 or more units of LTRA. This definition was issued from a scoping study provided by the CNAM (data not published).

c Defined as dispensation of oral or injectable corticosteroids within seven days of the GP visits.

${ }^{d}$ Defined as dispensation of R03 drugs within seven days of the GP visits.

e Defined as hospitalization, ER visits room or a visits to the general practitioner for exacerbation.

* Models were not run as the patients were different. 
Table 3. Estimation of SA impact for patients in the intervention and unexposed groups, sub-group analysis.

\begin{tabular}{|c|c|c|c|c|c|c|c|c|c|}
\hline & \multicolumn{3}{|c|}{$\begin{array}{c}\text { Patients with R03 } \geq 3 \text { in the year } \\
\text { prior } \\
\text { to program implementation }\end{array}$} & \multicolumn{3}{|c|}{ Patients with R03 $\geq 1$ in 2012} & \multicolumn{3}{|c|}{$\begin{array}{l}\text { Patients with asthma as defined } \\
\text { by the CNAM algorithm }\end{array}$} \\
\hline & $\begin{array}{l}\text { OR or } \\
\text { slope }\end{array}$ & $95 \% \mathrm{Cl}$ & $P$ value & $\begin{array}{l}\text { OR or } \\
\text { slope }\end{array}$ & $95 \% \mathrm{Cl}$ & $P$ value & $\begin{array}{l}\text { OR or } \\
\text { slope }\end{array}$ & $95 \% \mathrm{Cl}$ & $P$ value \\
\hline \multicolumn{10}{|l|}{ Process outcomes } \\
\hline \multicolumn{10}{|l|}{ Indicators of asthma control } \\
\hline ICS+LTRA/R03 $\geq 0.5$ & 0.98 & $\begin{array}{l}(0.95 \\
; 1.01)\end{array}$ & 0.2309 & 0.98 & $(0.95 ; 1 \cdot 02)$ & 0.3347 & 0.92 & $(0 \cdot 88 ; 0 \cdot 97)$ & 0.0014 \\
\hline$\geq 4 \mathrm{SABA}$ & $1 \cdot 04$ & $(1 \cdot 00 ; 1 \cdot 08)$ & 0.0630 & $1 \cdot 02$ & $\begin{array}{l}(0.99 \\
; 1.06)\end{array}$ & $0 \cdot 1880$ & 0.94 & $(0.90 ; 0 \cdot 99)$ & 0.0195 \\
\hline \multicolumn{10}{|l|}{ Controller medication } \\
\hline $\begin{array}{l}\text { At least one controller medication } \\
\text { dispensed }\end{array}$ & $1 \cdot 08$ & $(1 \cdot 04 ; 1 \cdot 13)$ & 0.0002 & 1.06 & $(1 \cdot 03 ; 1 \cdot 10)$ & 0.0006 & 0.94 & $\begin{array}{c}(0 \cdot 88 \\
1.01)\end{array}$ & $0 \cdot 1193$ \\
\hline $\begin{array}{l}\text { Sustained use of controller } \\
\text { medication }^{a}\end{array}$ & $1 \cdot 08$ & $\begin{array}{c}(1.04 \\
; 1.13) \\
\end{array}$ & $<0.0001$ & $1 \cdot 07$ & $(1 \cdot 03 ; 1 \cdot 11)$ & 0.0009 & $1 \cdot 04$ & $\begin{array}{c}(0.99 \\
1.09)\end{array}$ & $0 \cdot 1114$ \\
\hline $\begin{array}{l}\text { Total no. of R03 dispensed, mean } \\
\text { (SD) }\end{array}$ & $0 \cdot 51$ & $\begin{array}{l}(0.35 \\
; 0.67)\end{array}$ & $<0.0001$ & 0.39 & $\begin{array}{c}(0 \cdot 25 \\
0 \cdot 52)\end{array}$ & $<0.0001$ & $0 \cdot 34$ & $\begin{array}{l}(0 \cdot 09 \\
0.60)\end{array}$ & 0.0080 \\
\hline \multicolumn{10}{|l|}{$\begin{array}{l}\text { Adherence to controller asthma } \\
\text { medications }\end{array}$} \\
\hline MRA $>80 \%$ & $1 \cdot 09$ & $(1 \cdot 04 ; 1 \cdot 15)$ & 0.0007 & $1 \cdot 07$ & $(1 \cdot 02 ; 1 \cdot 13)$ & 0.0080 & $1 \cdot 08$ & $(1 \cdot 02 ; 1 \cdot 14)$ & 0.0139 \\
\hline \multicolumn{10}{|l|}{ Healthcare utilization outcomes } \\
\hline $\begin{array}{l}\text { Urgent care visits } \\
\text { At least one asthma-related } \\
\text { hospitalization }\end{array}$ & $0 \cdot 51$ & $(0 \cdot 39 ; 0 \cdot 67)$ & $<0.0001$ & $0 \cdot 50$ & $(0 \cdot 39 ; 0 \cdot 65)$ & $<0.0001$ & $0 \cdot 55$ & $(0 \cdot 40 ; 0 \cdot 74)$ & 0.0001 \\
\hline At least one ER visit for asthma & 0.97 & $(0.90 ; 1 \cdot 04)$ & 0.3588 & 0.97 & $(0.91 ; 1 \cdot 05)$ & 0.4610 & 0.93 & $(0 \cdot 84 ; 1 \cdot 02)$ & $0 \cdot 1024$ \\
\hline
\end{tabular}




\begin{tabular}{|c|c|c|c|c|c|c|c|c|c|}
\hline $\begin{array}{l}\text { At least one GP visit for asthma } \\
\text { exacerbation }{ }^{b}\end{array}$ & 0.98 & $(0 \cdot 95 ; 1 \cdot 01)$ & 0.2220 & 0.98 & $(0 \cdot 95 ; 1 \cdot 01)$ & $0 \cdot 1652$ & 0.94 & $(0 \cdot 90 ; 0 \cdot 98)$ & 0.0071 \\
\hline At least one pulmonologist visit & 1.01 & $(0.96 ; 1.06)$ & 0.6157 & 1.01 & $(0.96 ; 1.06)$ & 0.7163 & 0.99 & $(0.93 ; 1.05)$ & 0.7958 \\
\hline $\begin{array}{l}\text { At least one pulmonary function } \\
\text { testing }\end{array}$ & 0.98 & $(0.94 ; 1 \cdot 03)$ & 0.4548 & 0.98 & $(0.94 ; 1 \cdot 03)$ & $0 \cdot 4490$ & 0.96 & $(0 \cdot 90 ; 1 \cdot 02)$ & $0 \cdot 1700$ \\
\hline $\begin{array}{l}\text { Work absenteeism } \\
\text { No. of sickleave days related to } \\
\text { asthma, mean number (SD), days }\end{array}$ & $-0 \cdot 14$ & $\begin{array}{c}(-0.29 \\
0.02)\end{array}$ & 0.0934 & $-0 \cdot 14$ & $\begin{array}{c}(-0 \cdot 28 ;- \\
0.01)\end{array}$ & 0.0382 & $-0 \cdot 29$ & $\begin{array}{c}(-0.53 ;- \\
0.05)\end{array}$ & 0.0197 \\
\hline $\begin{array}{l}\text { At least one sickleave episode } \\
\text { related to asthma }\end{array}$ & 0.97 & $(0 \cdot 90 ; 1 \cdot 04)$ & $0 \cdot 3403$ & 0.96 & $(0.9 ; 1.03)$ & 0.2625 & 0.92 & $\begin{array}{l}(0.84 \\
; 1 \cdot 00)\end{array}$ & 0.0534 \\
\hline
\end{tabular}

Data are no. (\%) of patients, unless otherwise indicated. Values in bold indicate significant associations $(p<0.05)$.

ER, emergency room; ICS, inhaled corticosteroid; LABA, long-acting $\beta$-agonist; LTRA, leukotriene receptor antagonist; SABA, short-acting $\beta$ agonists.

a Defined as five or more units of ICS/LABA in a single inhaler and/or ICS as a single agent medicine, or 8 or more units of LTRA. This definition was issued from a scoping study provided by the CNAM (data not published).

${ }^{b}$ Defined as hospitalization, ER visits room or a visits to the general practitioner for exacerbation 


\section{FUGURES}

Figure 1 : Flow and selection of subjects records for inclusion into propensity analyses ; 


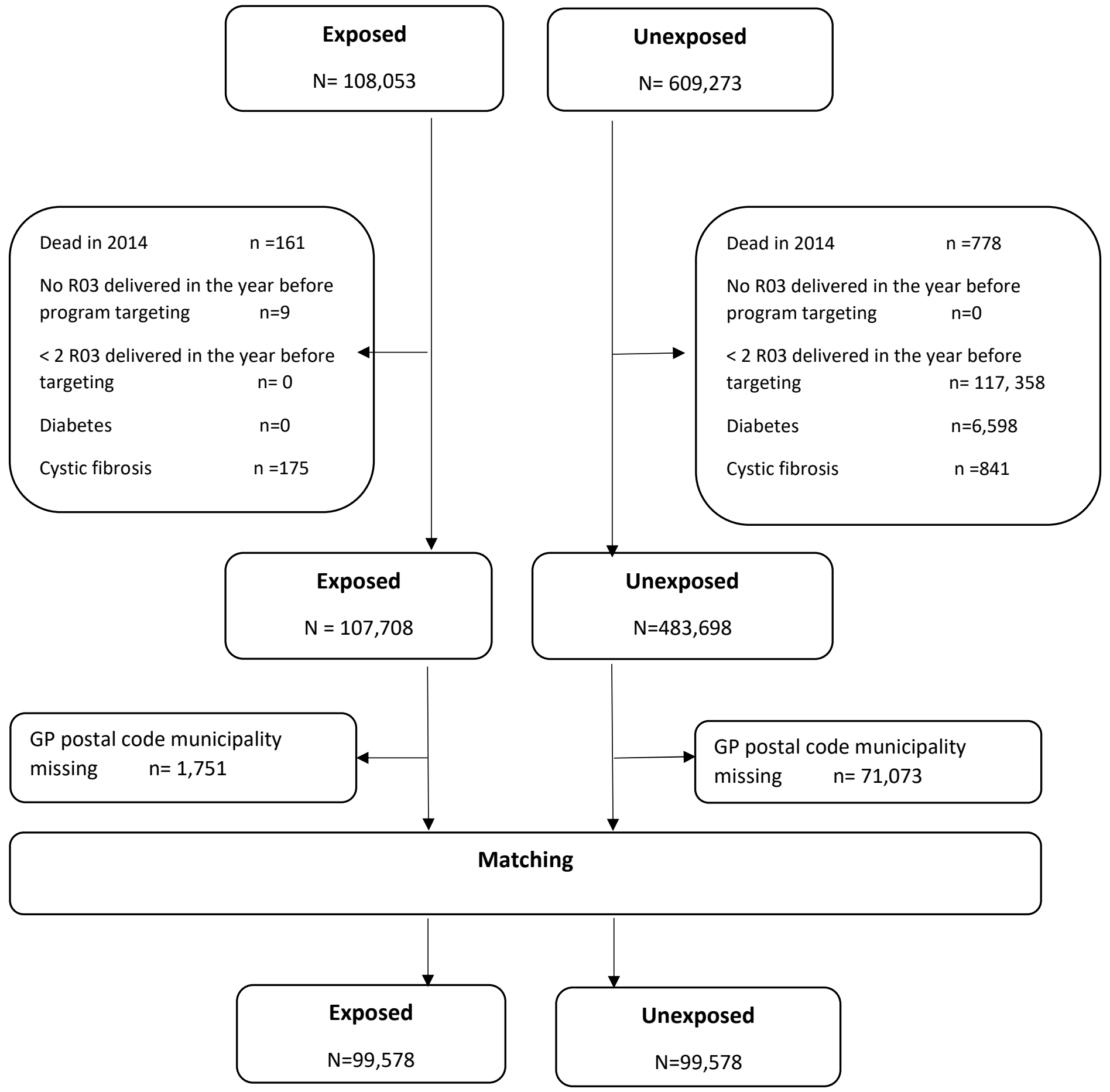

